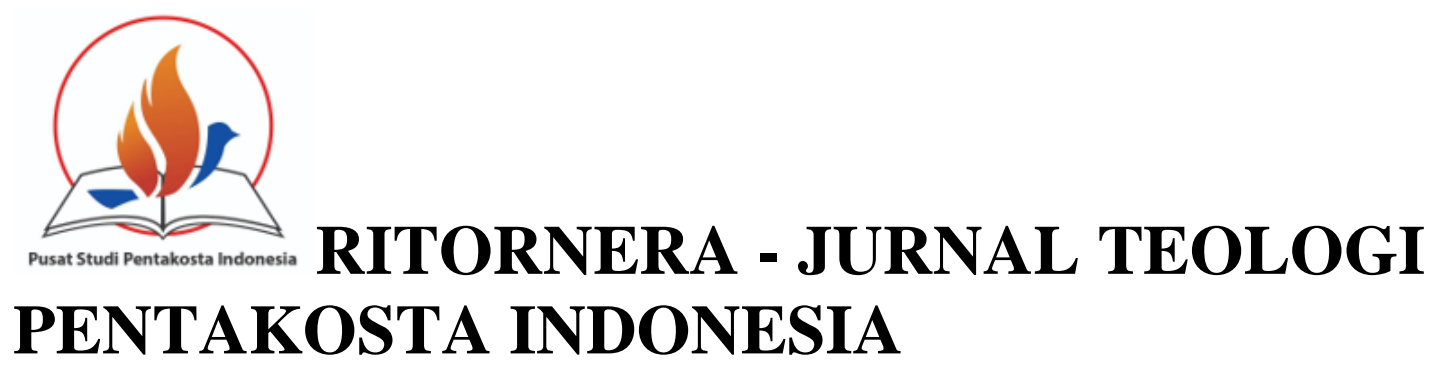

Vol. 1, No. 2, August 2021

Available at: pspindonesia.org

\title{
Kajian Teologi Misi dalam Roma 10:13-15 terhadap
}

\author{
Aktualisasi Misi Kristen \\ Yonatan Alex Arifianto \\ arifianto.alex@sttsangkakala.ac.id
}

\begin{abstract}
Evangelism as a means of bringing people together with God through testimony or example must continue to be echoed. However, there are many different paradigms and concepts of evangelism. Moreover, churches and believers are reluctant to do evangelism because they do not consider it their duty and responsibility. Indeed, believers do not escape the actualization of the mandate of the Great Commission of the Lord Jesus in preaching the gospel to humans. Using a descriptive qualitative method with a literature study approach, it can be concluded that the study of mission theology in Romans 10:13-15 on the actualization of Christian missions studied through exegesis can be concluded, First, evangelism must be carried out as part of the actualization of the mandate of the Great Commission by giving oneself to preach the news to others so that People who don't know Jesus can hear salvation only in Jesus. Second, the task of the believer is continued as a person who continues to preach by listening and proclaiming the gospel of salvation for humans. The three churches or leaders are obliged to send messengers of evangelists for the sake of saving souls.
\end{abstract}

Keywords: Mission Theology, Mission Actualization, Evangelism, Great Commission, Gospel

Abstrak

Penginjilan sebagai sarana mempertemukan manusia dengan Tuhan lewat kesaksian ataupun keteladanan harus terus digaungkan. Namun banyaknya perbedaan paradigma dan konsep pengijilan. Terlebih gereja maupun orang percaya enggan melakukan penginjilan karena bukan mengangap bahwa tugas dan tanggung jawabnya. Sejatinya orang percaya tidak luput dari aktualisasi mandat Amanat Agung Tuhan Yesus dalam melakukan pemberitaan Injil kepada manusia. Mengunakan meotode kualitatif deskritif dengan pendekatan studi literatur bahwa kajian Teologi misi dalam Roma 10:13-15 terhadap aktualisasi misi Kristen yang dikaji melalui eksegesa dapat disimpulkan, Pertama Penginjilan harus terus dilakukan sebagai bagian aktualisasi mandat Amanat Agung dengan memberi diri untuk memberitakan kabar bagi sesama sehingga orang yang belum mengenal Yesus dapat mendengar keselamatan hanya di dalam 
Yesus. Kedua, Tugas orang percaya dilanjutkan sebagai pribadi yang terus menerus melakukan pemberitaan dengan memperdengarkan dan memberitakan Injil keselamatan bagi manusia. Ketiga Gereja atau pemimpin wajib mengirimkan utusan Pemberita Injil demi jiwa-jiwa diselamatkan.

Kata kunci: Teologi Misi, Aktualisasi Misi, Penginjilan, Amanat Agung, Injil

\section{PENDAHULUAN}

Kekristenan yang selama ini bertumbuh dimulai dari para rasul dan murid yang menerima mandat untuk pergi keseluruh penjuru dunia. Namun saat ini pekabaran injil dari perspektif orang Kristen mengalami penurunan makna sehingga fakta yang terjadi di lapangan menunjukkan bahwa masih terdapat gereja lokal yang mengalami stagnasi dalam pelayanan penginjilan. ${ }^{1}$ Hal itu terjadi akibat adanya penghambat penginjilan dari dalam gereja serta ditambah lagi dengan adanya peran jemaat yang tidak melaksanakan pemberitaan Injil keluar bagi dunia non Kristen, walaupun pribadinya sebagai orang percaya. ${ }^{2}$ Banyak orang tidak mau menginjil karena memiliki konsep bahwa pemberitaan Injil sebagai tugas dan peran yang hanya dilakukan oleh para pemimpin gereja, pendeta, penginjil, atau pengkhotbah yang terkenal. ${ }^{3}$ Hambatan intern berdasarkan fakta diatas menjadi indikator bahwa penginjilan atau memberitakan kabar baik itu hanya pantas dikerjakan dan dilakukan oleh para pendeta maupun para pelayan Tuhan saja yang full time melayani Tuhan. Adapun paradigma injil yang salah yang

\footnotetext{
${ }^{1}$ Paulus Purwoto and Asih Rachmani Endang Sumiwi, "Pola Manajemen Penginjilan Paulus Menurut Kitab Kisah Para Rasul 9-28,” Angelion: Jurnal Teologi Dan Pendidikan Kristen 1, no. 2 (2020): 113-31, https://doi.org/10.38189/jan.v1i2.71.

${ }^{2}$ Kejar Hidup Laia, "Pertumbuhan Gereja Dan Penginjilan Di Kepulauan Nias," FIDEI: Jurnal Teologi Sistematika Dan Praktika 2, no. 2 (2019): 286-302, https://doi.org/10.34081/fidei.v2i2.46.

${ }^{3}$ Djuwansah Suhendro P Stephanus, "Mengajarkan Penginjilan Sebagai Gaya Hidup Orang Percaya," Redominate 1, no. 1 (2019): 12-22.
} 
selama ini mempengaruhi jemaat yang tidak mau dan tidak konsisten melaksanakan pemberitaan kabar keselamatan sebagai orang percaya. ${ }^{4}$

Angapan bahwa misi adalah pekerjaan gereja besar yang memiliki kapasitas dan kapabilitas kemampuan dana itulah yang mengerjakan misi. Bahkan banyak gereja yang memiliki pola pikir yang salah terhadap prinsip dan konsep penginjilan. ${ }^{5}$ Gembala dalam perannya sebagai leader penginjilan tidak termotivasi dan puasa dalam pencapaiannya ataupun adanya ketidakmauan pemimpin gereja atau gembala untuk menginjil akan memberikan keteladanan yang buruk bagi jemaat, akhirnya jemaat bermalas-malasan untuk menginjili. Hal ini akan berdampak pada pertumbuhan gereja secara kuntitatif karna tidak ada pertambahan jiwa baru yang diselamatkan melalui injil. Sebab peran gembala dalam memberitakan Injil harus menjadi contoh dan teladan bagi jemaatnya. ${ }^{6}$ Gereja dan orang percaya di sibukan dengan aktivitas rutunitas pelayanan Kristiani yang hampir seluruhnya hanya melayani orang-orang Kristen saja. ${ }^{7}$ sikap orang Kristen dalam mengaktualisasi misi banyak dipengaruhi rasa ketakutan apa yang di sampaikan ditolak ataupun akan mengahadapi aniaya karena pemberitaan misi tersebut. lantas hal itu memilih berdiam diri dengan alasan bertoleransi sampai lupa mengaktualisasi tugas amanat Agung. ${ }^{8}$

Hambatan eksternal pun terjadi yang disebabkan adanya konflik agama baik verbal maupun fisik yang terjadi selama ini dapat menghambat para pemimpin gereja atau orang

${ }^{4}$ Laia, "Pertumbuhan Gereja Dan Penginjilan Di Kepulauan Nias."

${ }^{5}$ Yonatan Alex Arifianto, Kristien Oktavia, and Matius I Totok Dwikoryanto, "Studi Teologis Prinsip Penginjilan Paulus Dalam 1 Korintus 9: 16," LOGIA: Jurnal Teologi Pentakosta 2, no. 1 (2020): 22-41, https://doi.org/10.37731/log.v2i1.42.

${ }^{6}$ Gideon Rusli and Yonatan Alex Arifianto, "Tinjauan Teologis Peran Gembala Dalam Aktualisasi Misi Berdasarkan 2 Timotius 4: 1-2," Sabda: Jurnal Teologi Kristen 2, no. 1 (2021): 299-316.

${ }^{7}$ Darsono Ambarita, Perspektif Misi Dalam Perjanjian Lama Dan Perjanjian Baru (Medan: Pelita Kebenaran Press, 2018), 35.

${ }^{8}$ Laia, "Pertumbuhan Gereja Dan Penginjilan Di Kepulauan Nias." 
percaya menginjil. Namun Penginjilan sebagai salah satu tugas esensial gereja mengharuskan orang percaya untuk melakukannya, sekalipun berada di tempat yang penuh tantangan dan rintangan. ${ }^{9}$ Tantangan, rintangan dan persoalan baik internal maupun ekternal yang dihadapi dalam penginjilan, semestinya tidak menciutkan para pekabar Injil, apalagi menghentikan aktivitas penginjilan. Kesulitan, hambatan atau apa pun alasannya semestinya mendorong para penginjil atau umat Allah untuk berserah pada Allah. ${ }^{10}$ Kewajiban mengabarkan Injil adalah tanggung jawab setiap orang yang telah menerima Yesus Kristus sebagai Tuhan dan Juruselamat. Setiap mereka yang percaya wajib mengabarkan Injil sesuai kemampuan dan karunia-karunia yang dianugerahkan Roh Kudus kepadanya. ${ }^{11}$ Sejatinya kewajiban mengabarkan Injil tidak terbatas kepada pendeta maupun pemimpin Gereja semata-mata, ia juga menjadi tanggung jawab setiap orang yang menyakini Kristus sebagai Tuhan. ${ }^{12}$

Berkaitan dengan topik Kajian Teologi Misi dalam Roma 10:13-15 terhadap Aktualisasi Misi Kristen pernah diteliti dalam penelitian ilmiah oleh Linus Baito dengan judul penelitiannya Faktor Meme Dalam Penginjilan : Sebuah pendekatan Interatif dalam memahami Roma 10:1415 berdasarkan perspektif meme machine. ${ }^{13}$ Kesimpulan dari penelitian tersebut adalah bahwa Perintah untuk menjadikan semua bangsa murid Yesus (Matius 28:19-20), perintah untuk meneruskan "berita" yang telah diterima kepada orang lain yang dapat dipercaya (2 Timotius 2:2), dan perintah untuk memberitakan firman Allah dalam segala waktu-baik atau tidak baik

${ }^{9}$ Alvin Kristian, "Pemberitaan Injil Di Tengah Masyarakat Pluralis," Excelsis Deo: Jurnal Teologi, Misiologi, Dan Pendidikan 3, no. 1 (2019): 123-32, https://doi.org/10.51730/ed.v3i1.5.

${ }^{10}$ Rinawaty and Hannas, "Menerapkan Model Penginjilan Pada Masa Kini," Kurios (Jurnal Teologi Dan Pendidikan Agama Kristen) 5, no. 2 (2019): 175-89, https://www.sttpb.ac.id/ejournal/index.php/kurios/article/download/118/75.

${ }^{11}$ David W Ellis, Metode Penginjilan: Istimewa Tepat Guna Bagi Penginjil Awam Praktis Dan Taktis (Yayasan Komunikasi Bina KASIH/OMF, 2005), 7.

${ }^{12}$ M R B Zakaria, "Metode Penginjilan Dalam Agama Kristen Katolik” (Universitas Islam Negeri Sultan Syarif Kasim Riau, 2011), http://repository.uin-suska.ac.id/206/.

${ }^{13}$ Linus Baito, "Faktor Meme Dalam Penginjilan : Sebuah Pendekatan Interatif Dalam Memahami Roma 10:14-15 Berdasarkan Perspektif Meme Machine," SOLA GRATIA: Jurnal Teologi Biblika Dan Praktika 6, no. 2 (2020), https://doi.org/10.47596/solagratia.v6i2.79. 
waktunya (2 Timotius 4:2). Ketiga bagian Alkitab tersebut memang merupakan sebuah pesan atau amanat yang harus dikerjakan dari seseorang kepada orang lain lagi. Adinia Mendrofa juga melakukan penelitian serupa dalam artikel berjudul Analisis tentang Keselamatan Menurut Roma 10:4-15 dan Aplikasinya Bagi Orang Percaya. ${ }^{14}$ Dengan kesimpulan bahwa Keselamatan ini akan ditawarkan kepada semua orang melalui penginjilan yang menjadi tanggung jawab setiap orang percaya. Berdasarkan kedua penelitian tersebut masih ada hal-hal yang belum diteliti yaitu tentang

Kajian Teologi Misi dalam Roma 10:13-15 terhadap Aktualisasi Misi Kristen. Oleh sebab itu artikel ini akan meneliti dan membahas tentang topik tersebut dalam kajian eksegesa dan memaknai teks sebagai kajian misi Kristen.

\section{METODE}

Metode penelitian dalam penulisan artikel adalah metode kualitatif deskriptif, ${ }^{15}$ dengan pendekatan studi literatur dan eksegesa kajian teks dalam Roma 10:13-15. Untuk dapat memaparkan tentang kajian teologi misi dalam Roma 10:13-15 terhadap aktualisasi misi Kristen, maka penulis melakukan studi pustaka terhadap berbagai sumber literatur berupa jurnal teologi ataupun buku-buku yang sesuai dengan tema misiologi, sehingga diperoleh gambaran teologi misi Roma 10:13-15 dan aktualisasi misi Kristen. Dalam proses penelitian, langkah pertama, penulis berusaha menggali aspek-aspek dan hakikat serta paradigma misi. Kemudian, penulis menggali teologi Paulus dalam Misi. Penulis juga memberikan implikasi bagi misi Kristen. Penulis memanfaatkan berbagai sumber, seperti Alkitab, buku, jurnal, tafsiran, dan

\footnotetext{
${ }^{14}$ Adinia Mendrofa, “Analisis Tentang Keselamatan Menurut Roma 10: 4-15 Dan Aplikasinya Bagi Orang Percaya," HAGGADAH: Jurnal Teologi Dan Pendidikan Kristen 1, no. 2 (2020): 87-93.

${ }^{15}$ Umrati and Hengki Wijaya, Analisis Data Kualitatif Teori Konsep Dalam Penelitian Pendidikan (Sulawesi Selatan: Sekolah Tinggi Theologia Jaffray, 2020), 12.
} 
artikel ilmiah untuk mendapatkan data yang lengkap. Hal tersebut dilakukan untuk memperkaya kajian yang dilakukan oleh penulis.

\section{HASIL DAN PEMBAHASAN}

Teologi misi Paulus didasari atas kepeduliaannya kepada bangsanya yang belum selamat. $^{16}$ Dalam Roma pasal 1 menekankan bahwa Injil adalah kekuatan Allah yang menyelamatkan setiap orang percaya, pertama-tama orang Yahudi, tetapi juga orang Yunani, sebab didalamnya nyata kebenaran Allah, yang bertolak dari iman dan memimpin kepada iman, seperti ada tertulis, orang benar akan hidup oleh iman. Pengakuan Rasul Paulus yang berani ini yang didasarkan pada keunggulan Injil. ${ }^{17}$ Seperti yang dialami oleh Rasul Paulus yang mengalami perubahan hidup yang sangat signifikan atau transformasi kehidupan yang secara umum dikenal dengan pertobatan dari seorang Farisi menjadi seorang rasul Tuhan Yesus Kristus yang sangat militan yang kuat dalam melayani Tuhan. ${ }^{18}$ Sebab paulus juga menyatakan bahwa Injil berbicara tentang sentralitas Kristus yang sesuai relevansi misinya dalam merintis jalan kemenangan Allah. ${ }^{19}$ Untuk diberitakan kepada mereka yang belum menerima keselamatan. Sebab manusia yang mengambil keputusan percaya dan berseru kepada Yesus maka kuasa Injil yang menyelamatkan dan menjadi bagiannya. ${ }^{20}$

\section{Hakikat dan Paradigma Penginjilan}

\footnotetext{
${ }^{16}$ Nidia Anggraini and Dicky Dominggus, "Mengajarkan Sikap Patriotisme Melalui Pemaknaan Roma 9:3," LOGIA: Jurnal Teologi Pentakosta 1, no. 2 (2020): 23-40, https://doi.org/10.37731/log.v1i2.34.

${ }^{17}$ Henry's Matthew, "Matthew Henry Commentary On Whole Bible," 2002, https://www.biblestudytools.com/commentaries/matthew-henry-complete/Roma/2.html.

18 Yusak Tridarmanto, "Spiritualitas Rasul Paulus," Gema Teologi: Jurnal Teologi Kontekstual Dan Filsafat Keilahian 39, no. 1 (2015): 15-32, https://journal-theo.ukdw.ac.id/index.php/gema/article/view/191.

${ }^{19}$ David J. Bosch, Tranformasi Misi Kristen, Sejarah Teologi Misi Yang Mengubah Dan Berubah (Jakarta: BPK Gunung Mulia, 2018), 219.

${ }^{20}$ Henry's Matthew, "Matthew Henry Commentary On Whole Bible."
} 
Kata misi dalam bahasa Inggris yakni mission dan missions secara esensi. Mission berarti pekerjaan-pekerjaan spesifik yang dilakukan oleh gereja untuk menunjukkan kepada para pemimpin atau jemaat gereja melayani terpusat kepada kerajaan Allah. ${ }^{21}$ Tugas pemberitaan Injil, yang secara praktis dalam keseharian dapat diistilahkan bersaksi bagi Kristus, bukan semata-mata tugas orang Kristen "yang terpanggil secara pribadi” saja (misalnya Evangelis, Misionaris, Pendeta), namun merupakan tugas setiap orang Kristen yang sudah diselamatkan. Tugas ini merupakan keharusan bagi setiap orang yang beriman kepada Yesus Kristus, agar dapat ambil bagian dalam Injil. ${ }^{22}$ Sehingga orang percaya dalam pelayanan memberitakan Injil tidak bisa dipisahkan dari pengabdian dan ketundukan terhadap Amanat Agung Tuhan Yesus. ${ }^{23}$

Maknanya penginjilan berasal dari kata "evanggeliso" evanggeliso kata ini merupakan satu istilah yang dipakai dalam kemiliteran Yunani. Yang memiliki arti upah yang diberikan kepada pembawa berita kemenangan dari medan tempur, dan atau berita kemenangan itu sendiri. Kemudian orang Kristen menggunakan kata "evanggeliso" untuk menjelaskan "berita" tentang pengorbanan dan atau karya Yesus Kristus sebagai sebuah kabar baik. Kata evanggeliso sinonim

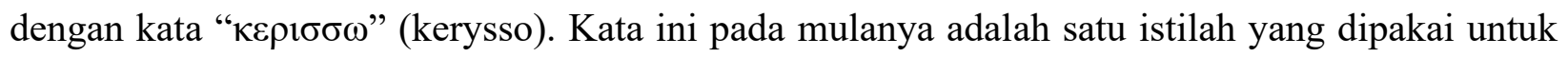
seorang utusan resmi (utusan itu disebut kerux) yang menyampaikan pengumuman dari raja. ${ }^{24}$ Makna lainnya yang dinyatakan oleh Schnabel bahwa pemberitaan Injil mengandung arti memberitakan kabar baik "announce good news" atau juga dapat dinyatakan sebagai seseorang yang sedang berkhotbah tentang Injil "Proclaim, preach the gospel". Terlebih dapat diartikan

\footnotetext{
${ }^{21}$ Yosua Feliciano Camerling and Hengki Wijaya, "Misi Dan Kebangkitan Rohani: Implikasi Misi Allah Bagi Gereja," Jurnal Ilmiah Religiosity Entity Humanity (JIREH) 1, no. 1 (2019): 57-71.

${ }^{22}$ Seri Damarwanti, "Pandangan Rasul Paulus Tentang Jembatan Pengantar Injil. Kajian Misiologi Terhadap I Korintus 9:1-23,” Sanctum Domine: Jurnal Teologi 8, no. 2 (2020): 95-132, https://doi.org/10.46495/sdjt.v8i2.53.

${ }^{23}$ Kosma Manurung, "Efektivitas Misi Penginjilan Dalam Meningkatkan Pertumbuhan Gereja," DUNAMIS: Jurnal Teologi Dan Pendidikan Kristiani 4, no. 2 (2020): 225-33, https://doi.org/10.30648/dun.v4i2.242.

${ }^{24}$ Yakob Tomatala, Penginjilan Masa Kini 1 (Malang: Gandum Mas, 2018), 24.
} 
dengan seseorang yang aktif dalam mengabarkan kabar baik "have good news atau the gospel preached to one". ${ }^{25}$ Misi juga memiliki makna sebagai suatu mandat dengan memiliki satu tujuan penyelamatan umat manusia dengan memperkenalkan Yesus Kristus sebagai Tuhan dan Juru selamat secara pribadi kepada manusia. ${ }^{26}$ Juga dapat dinyatakan sebagai aktifitas dan kerinduan hati Allah yang sangat besar yaitu karya penyelamatan umat manusia agar kembali kepadaNya. ${ }^{27}$ Misi juga dimaknai sebagai kerinduan Allah yang bekerja sama dengan orang yang percaya kepadaNya bahwa Tuhan selalu ada untuk dunia untuk memberikan keselamatan manusia. ${ }^{28}$ Oleh karena itu adanya tugas penginjilan tidak dapat disepelekan dan menganggap hal biasa, karena berita keselamtan dan kabar baik itu menyangkut keselamatan jiwa banyak orang yang mana jiwa-jiwa tersebut sangat berharga dihadapan Allah. ${ }^{29}$

Tujuan misi yang diungkapkan oleh Santoso adalah Pertama, Conversio gentilium yang memiliki makna bahwa misi untuk pertobatan orang-orang kafir, memberitakan Injil di daerahdaerah yang belum mengenal Injil. Atau untuk memenangkan jiwa-jiwa bagi Kristus, (Matius 28: 19). Kedua, Plentatio ecclesiae yang bermakna bahwa misi untuk penanaman gereja, pendirian jemaat atau gereja lokal. Menampung petobat baru dalam komunita untuk pertumbuhan rohani mereka. Hal itu bertujuan sebagai bagaian dari pelipatgandaan pertumbuhan jemaat. misi untuk penanaman gereja diprioritaskan karena saat ini banyak perintisan yang berorientasi pada pertumbuhan gereja maka salah satu hal yang dapat dilakukan sebagai fondasi dalam pelayanan

\footnotetext{
${ }^{25}$ Eckhard J. Schnabel, Paul The Missionary (Downers Grove: InterVarsity, 2008), 226.

${ }^{26}$ Nur Budi Santosa, "Pelayanan Sosial Sebagai Konteks Refleksi Aktivitas Misiologi," Jurnal Antusias 2, no. 4 (2013): 126-37, http://sttintheos.ac.id/e-journal/index.php/antusias/article/view/28/27.

${ }^{27}$ Santosa.

${ }^{28}$ Fernando Tambunan, "Tantangan Misi Dalam Prespektif Pemikiran Era Postmodern," in Seminar Mission Today, 2017, https://doi.org/10.1017/CBO9781107415324.004.

${ }^{29}$ Stephanus, "Mengajarkan Penginjilan Sebagai Gaya Hidup Orang Percaya."
} 
adalah misi untuk penanaman gereja. ${ }^{30}$ Sejatinya gereja harus menghasilkan buah dan mengembangkan pengaruh sampai ke ujung bumi. Karena adanya kerinduan dan rancangan Tuhan bagi gereja-Nya sebagai alat misiNya harus berjalan progresif (Mat 16: 18). Ketiga, Gloria et manifestatia gratiae divinae yang berarti bahwa misi bertujuan sebagai wujud manusia untuk memuliakan Allah sebab keselamatan yang dianugrahkan tersebut menjadi ucapan syukur memuliakan Tuhan. karena tanpa disadari setiap orang yang mengalami pertobatan dan perjumpaan dengan Tuhan serta kelahiran kembali sebagai manusia yang dibaharui untuk memulikan Allah. ${ }^{31}$ Misi adalah sebuah nilai kerjasama Allah dan orang yang percaya kepadaNya yang telah masuk dalam keselamatan Kristus dengan merespon panggilan Allah tersebut. dengan bertanggung jawab untuk memberitakan Yesus Kristus sebagai central pemberitaan. ${ }^{32}$ Dan sebagai respon terhadap mandat Amanat Agung sebagai prioritas pelayanan (Markus. 16:1516). ${ }^{33}$

Tujuan misi diatas sangat selaras dengan konsep yang diberikan Paulus menekankan kepada orang percaya untuk terus melakukan bagiannya di market place yang Tuhan sudah tentukan di kehidupannya untuk giat dalam pemberitaan Injil.

\section{Eksegesis Roma 10:13-15}

\section{Memberi diri dalam seruan kepada Allah}

Roma 10:13 for, "Everyone who calls on the name of the Lord ${ }^{a}$ will be saved. (NIV)

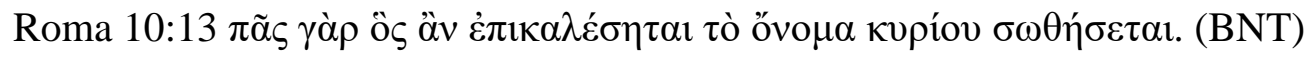

\footnotetext{
${ }^{30}$ Yesri Talan, "Mengkaji Hakekat Misi Inklusif Yesus Berdasarkan Injil Lukas Dan Aplikasinya Bagi Misi Masa Kini," Manna Rafflesia 6, no. 2 (2020): 200-219.

${ }^{31}$ Santosa, "Pelayanan Sosial Sebagai Konteks Refleksi Aktivitas Misiologi."

${ }^{32}$ Mira Marleni Pandie, "Misteri Allah Dalam Pandangan Paulus Dan Implikasinya Bagi Pemberitaan Masa Kini,” Jurnal Jaffray, 2012, https://doi.org/10.25278/jj.v10i2.059.166-179.

${ }^{33}$ Stephanus, "Mengajarkan Penginjilan Sebagai Gaya Hidup Orang Percaya."
} 
Roma 10:13 Sebab, barangsiapa yang berseru kepada nama Tuhan, akan diselamatkan. (ITB) ${ }^{34}$

Kata Berseru mengunakan kata $\pi \iota \kappa \alpha \lambda \varepsilon ́ o \mu \alpha \iota$ atau epikaleomai memiliki kata kerja verb subjunctive aorist middle 3 rd person singular from $\dot{\varepsilon} \pi \iota \alpha \lambda \varepsilon \dot{\varepsilon} \omega .{ }^{35}$ yang memiliki arti for aid, worship, testimony, decision (untuk meminta bantuan, sebagai konsep ibadah, kesaksian). ${ }^{36}$ juga dapat diartikan sebagai to invoke atau memanggil, berseru, memanggil, dan juga dapat diartikan sebagai orang yang mau melibatkan diri. Kata barangsiapa yang berseru, yaitu orang per orang, tanpa kecuali. Kesamaan hak yang dimiliki bangsa Yahudi dan bangsa bukan Yahudi untuk memperoleh janji keselamatan tersebut. ${ }^{37}$ Maka adanya Keselamatan kepada manusia yang berseru atau mau melibatkan diri dalam setiap kepercayaannya iman kepada Yesus, maka pasti terjadi sebab sejatinya Allah selalu menolong setiap orang yang berseru kepada-Nya. Oleh karena itu injil yang diberitakan memberikan dampak yang positif bagi setiap manusia yang memercayainya.

Injil tidak saja memberikan dampak transformasi spiritual tetapi juga transformasi sosial. Injil mentransformasi keadaan rohani manusia yang berdosa dan patut dihukum, menjadi anakanak Allah yang diselamatkan di dalam Yesus Kristus. ${ }^{38}$ Inilah bukti bahwa keselamatan adalah tindakan bagi manusia untuk mengungkapkan atau mendeklarasikan bahwa manusia membutuhkan Tuhan. dari kata berseru dapat memberi nilai bahwa keselamatan datang dari inisiatif Allah untuk menyelamatkan manusia dari dosa adalah dari Tuhan sendiri. Mengapa? Selain karena didasari oleh anugrah dan kasih kemurahan-Nya, juga karena

${ }^{34}$ BibleWorks ceased operation as a provider of Bibleworks, "BibleWorks," 2018.

${ }^{35}$ Bibleworks.

${ }^{36}$ Rick Meyers, "E-Sword®” (Franklin, TN 37065 United States of America: Rick Meyers All Rights Reserved Worldwide, 2020).

${ }^{37}$ Tafsiran Online. Henry Matthew Commentary, "Henry Matthew Commentary, Tafsiran Online.," n.d.

${ }^{38}$ David Eko Setiawan, "Dampak Injil Bagi Transformasi Spiritual Dan Sosial," BIA': Jurnal Teologi Dan Pendidikan Kristen Kontekstual 2, no. 1 (2019): 83-93. 
faktor keterbatasan dan ketidakmampuan manusia untuk menyelesaikan permasalahan dosanya. Itulah sebabnya Allah sendiri yang melibatkan diri dalam campur tangan untuk menyelamatkan umatNya dari belengu dosa dan hukuman kekal. Manusia yang berdosa hanya dituntut untuk mengakui dengan mulutnya dan percaya dengan segenap hati kepada Yesus Kristus, sehingga ia akan diselamatkan.

\section{Memperdengarkan dan memberitakan Injil}

Roma 10:14 How, then, can they call on the one they have not believed in? And how can they believe in the one of whom they have not heard? And how can they hear without someone preaching to them? (NIV)

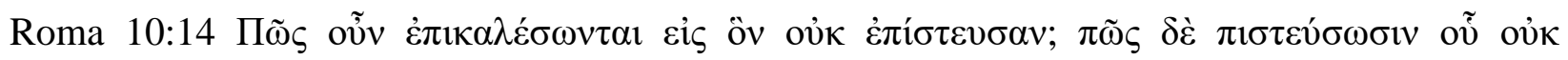

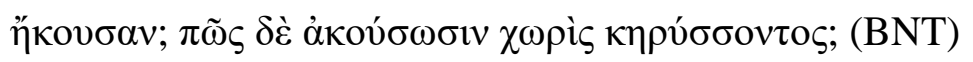

Roma 10:14 Tetapi bagaimana mereka dapat berseru kepada-Nya, jika mereka tidak percaya kepada Dia? Bagaimana mereka dapat percaya kepada Dia, jika mereka tidak mendengar tentang Dia. Bagaimana mereka mendengar tentang Dia, jika tidak ada yang memberitakan-Nya? $(\mathrm{ITB}) .{ }^{39}$

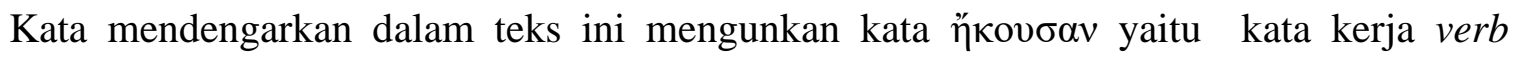

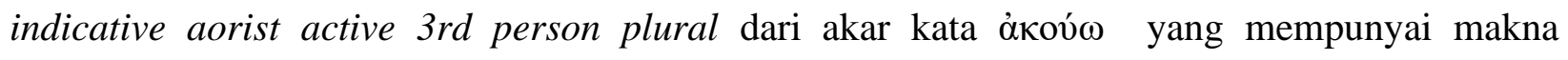
mendengar yang juga menyala, merespon dengan iman dari apa yang didengarkan Dalam Mat

\footnotetext{
${ }^{39}$ Bibleworks, "BibleWorks."
} 
11:5. Atau juga dapat diartikan sebagai Perhatikan, dengarkan 18:15, pahami 1 Kor 14:2; Gal 4:21. Pelajari atau dipahami dari Rom 10:18. ${ }^{40}$ Bagaimana seseorang dapat percaya kepada Yesus bila orang itu tidak pernah mendengar atau memahami sampai kepada keputusan untuk menerima dan percaya bahwa Yesus adalah Allah. Bagaimana supaya mereka yang ingin mendengar tentang Kristus dapat menjadi mengerti dan mengambil keputusan. Yaitu dengan memberitakan hanya tentang Dia atau Yesus Kristus sebagai pusat pemberitaan Injil. Yesus adalah pusat pemberitaan dari kabar keselamatan yang harus di siarkan kepada bangsa-bangsa. Sebab kabar keselamatan tersebut memberitakan kesaksian akan karya Allah yang berpusat dalam pribadi Yesus yang disalibkan. ${ }^{41}$ Yesus adalah benar-benar pribadi nyata berada di dalam sejarah, bahkan menjadi pusat sejarah yang saat juga tetap menjadi pusat misi bagi manusia. ${ }^{42}$ Sebab sejatinya Yesus Kristus sebagai satu-satunya Juruselamat umat manusia tanpa kecuali. Bahkan sebagaimana diungkapkan Alkitab bahwa Dia bukan hanya Juruselamat saja, tapi sekaligus Tuhan yang berinkarnasi menjadi manusia sebagai pusat keselamatan dan kehidupan kekal manusia. ${ }^{43}$

Memperdengarkan dan memberitakan adalah suatu menyatakan sikap bahwa misi merupakan tindakan keselamatan dari Allah Bapa, Allah Anak dan Allah Roh Kudus dengan tujuan membawa kehidupan kekal. ${ }^{44}$ Namun hal itu dapat diwujudkan dari panggilan Tuhan yang mau bekerja sama dengan manusia adalah bentuk dari sikap respon terbaik manusia menjadi pemberita Injil. Hal itu dipengaruhi motivasi bahwa jiwa sangat berharga bagi Tuhan.

\footnotetext{
${ }^{40}$ Bibleworks.

${ }^{41}$ Gratia Yada Putra et al., "Pengembangan Model Pendidikan Agama Kristen Bagi Anak Korban Kemiskinan," Jurnal Ecodunamika 3, no. 1 (2020).

${ }^{42}$ Kalis Stevanus, "Relevansi Supremasi Kristus Bagi Pemberitaan Injil Di Indonesia: Eksegesis Injil Yohanes 14: 6,” KAMASEAN: Jurnal Teologi Kristen 2, no. 1 (2021): 32-46.

${ }^{43}$ Kalis Stevanus, "Bukti Keilahian Yesus Menurut Injil," Jurnal Teruna Bhakti 2, no. 2 (2020): 82, https://doi.org/10.47131/jtb.v2i2.49.

${ }^{44}$ Santosa, "Pelayanan Sosial Sebagai Konteks Refleksi Aktivitas Misiologi."
} 
Sehingga memberikan kepekaan rohani terhadap jiwa-jiwa yang belum diselamatkan dan sebab sejatinya orang yang belum percaya kepada Yesus sedang dalam perjalanan menuju kekekalan tanpa Kristus. ${ }^{45}$

Seorang pribadi yang dipanggil dalam pemberita Injil diharap tidak hanya memahami inti berita Injil, tetapi juga harus hidup sesuai dengan kebenaran injil untuk menjadi terang dan berdampak bagi manusia. ${ }^{46}$ Dengan menjauhi sifat dan cara hidup yang salah, dan hal itu tidak datang dari nilai injil. ${ }^{47}$ Sebab sejatinya peran Injil yang diberitakan bagi manusia tidak sekadar berdampak pada keadaan nilai spiritual manusia, namun juga memberikan dampak bagi perubahan sosial manusia. ${ }^{48}$ Memperdengarkan Injil adalah suatu tindakan dengan sadar untuk memanggil manusia yang belum mengenal kebenaran untuk bertobat dan meninggalkan cara hidup yang lama.

Berita sukacita tersebut bertujuan memberitakan pengampunan dosa dan kehidupan kekal dalam Yesus serta mengundang mereka untuk menjadi komunitas dalam pertumbuhan iman yang hidup sehingga dapat berlanjut memulai pelayanan kepada orang lain di dalam naungan dan kuat kuasa Roh Kudus. ${ }^{49}$ Sebab keterlibatan kuasa Allah dalam proses penjangkauan jiwa sampai kepada pelayanan dalam seluruh market place adalah bukti kerja sama manusia

\footnotetext{
${ }^{45}$ M. David Sills, Panggilan Misi (Surabaya: Momentum, 2011), 15.

46 Tumpal H Hutahaean, "Signifikansi Apologetika Dalam Penginjilan," Stulos 17, no. 1 (2019): 54-74, http://www.sttb.ac.id/jurnal-teologi-stulos-vol-17-no-1.

${ }^{47}$ Harming Harming, "Metode Penginjilan Yesus Dalam Injil Yohanes 4:1-42," Evangelikal: Jurnal Teologi Injili Dan Pembinaan Warga Jemaat 1, no. 2 (2017): 162, https://doi.org/10.46445/ejti.v1i2.73.

48 Setiawan, "Dampak Injil Bagi Transformasi Spiritual Dan Sosial."

${ }^{49}$ David J. Bosch, Transformasi Misi Kristen Sejarah Teologi Misi Yang Mengubah Dan Berubah (Jakarta: BPK Gunung Mulia, 2000), 40.
} 
mengandalkan Allah. ${ }^{50}$ Itulah esensi sejati dari penginjilan bahwa hal penting dari setiap penyampaian kabar baik bagi manusia atas apa yang diperbuat Allah di dalam karya keselamatan melalui Yesus Kristus, dengan tujuan pengampunan dosa dan pendamaian manusia serta penebusannya. ${ }^{51}$ Yesus pusat pemberitaan menjadi landasan dari perintah Yesus atau mandatNya kepada murid-muridNya agar para murid memperhatikan dan menjadi kawan sekerja-Nya. ${ }^{52}$ Karena bagaimanapun juga injil harus diberitakan kepada semua makhluk, penginjilan merupakan sebuah keharusan bagi orang percaya untuk menyampaikan pesan Allah yang dapat diterima, dimengerti dan bertujuan menyelamatkan pendengarnya. ${ }^{53}$

\section{Mengirimkan Pemberita Injil}

Roma 10:15 And how can they preach unless they are sent? As it is written, "How beautiful are the feet of those who bring good news!" (NIV)

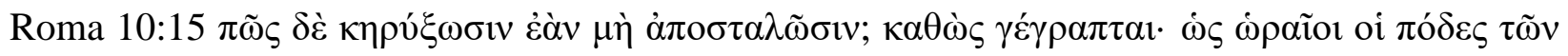
$\varepsilon \cup ̉ \alpha \gamma \gamma \varepsilon \lambda 1 \zeta o \mu \varepsilon ́ v \omega v[\tau \grave{\alpha}] \grave{\alpha} \gamma \alpha \theta \dot{\alpha}$. (BNT)

Roma 10:15 Dan bagaimana mereka dapat memberitakan-Nya, jika mereka tidak diutus? Seperti ada tertulis: "Betapa indahnya kedatangan mereka yang membawa kabar baik!"(ITB). ${ }^{54}$

Kata diutus dalam Alkitab versi NIV menggunkan kata Sent dalam bahasa Yunaninya

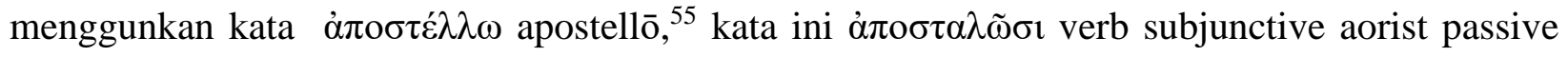

\footnotetext{
${ }^{50}$ Damarwanti, "Pandangan Rasul Paulus Tentang Jembatan Pengantar Injil. Kajian Misiologi Terhadap I Korintus 9:1-23.”

${ }^{51}$ Sarah Andriani, "Refleksi Guru Pendidikan Agama Kristen Sebagai Misionaris Di Dalam Pendidikan," Jurnal Antusias: Jurnal Teologi Dan Pelayanan 2, no. 4 (2013): 1-16.

${ }^{52}$ Putra et al., "Pengembangan Model Pendidikan Agama Kristen Bagi Anak Korban Kemiskinan."

${ }^{53}$ George W. Peters, Teologi Alkitab Tentang Pekabaran Injil (Malang: Gandum Mas, 2006), 239.

${ }^{54}$ Bibleworks, "BibleWorks."

${ }^{55}$ Rick Meyers, "E-Sword®."
} 


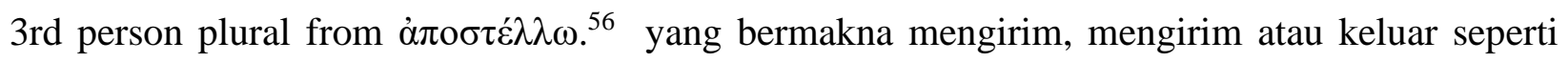
dalam Matius 13:41; 14:35; Markus 8:26; 12:2, 13; Lukas 1:19, 26; Kisah Para Rasul 5:21; 1 Korintus 1:17; terlebih dalam khususnya dalam misi ilahi Matius 10:5; Markus 9:37; Kisah Para Rasul 3:20.57 Mengirim utusan Injil menajadi bagian penting dalam rangkaian teologis misi dalam Roma 10:13-15. Gereja dan orang percaya diharap terlibat aktif membawa pesan keselamatan bagi mereka yang belum pernah mendengarkan. Yesus adalah kunci dari keselamatan manusia maka hal itu menjadi dasar untuk memberitakan Injil kepada semua bangsa. oleh karena itu gereja dan orang percaya bertanggungjawab penuh dalam melaksanakan misi Allah, sebab dengan menjadi kawan sekerja-Nya dan masuk kedalam misiNya bagi dunia, maka gereja mempunyai tanggung jawab besar dalam mentatati dan merealisasikan tugas panggilan tersebut. ${ }^{58}$ Oleh sebab itu kekristenan dalam kehidupan sehari-hari secara personal juga dapat mengirimkan dirinya atau mau melibatkan diri sebagai pemberita Injil di market place yang telah ditetapkan. Namun seorang yang rela memberitakan Injil harus bersungguh-sungguh sebab tidak ada penjangkauan jiwa yang berhasil dari usaha yang setengah-setengah. Oleh karena itu orang percaya sangat diperlukan totalitas. Totalitas misi merupakan prinsip kerja yang berarti mau melakukan apapun untuk memberitakan Injil dan memenangkan jiwa bagi Tuhan. ${ }^{59}$ sebagai tanda siap diutus bagi pekerjaan misi.

Gereja juga diharapkan berperan untuk dapat mengirimkan jemaat untuk diperlangkapi baik secara formal dalam pendidikan teologi atau informal pendidikan gereja sendiri untuk keluar memberitakan Injil bagi semua orang. Gereja juga dapat bekerja sama dengan gereja

\footnotetext{
${ }^{56}$ Bibleworks, "BibleWorks."

57 Bibleworks.

${ }^{58}$ Fransiskus Irwan Widjaja, Daniel Ginting, and Sabar Manahan Hutagalung, "Teologi Misi Sebagai Teologi Amanat Agung," Thronos 1, no. 1 (2019): 17-24.

${ }^{59}$ Damarwanti, "Pandangan Rasul Paulus Tentang Jembatan Pengantar Injil. Kajian Misiologi Terhadap I Korintus 9:1-23.”
} 
denominasi lainnya untuk mendukung para penginjil dan memperlengkapi setiap kebutuhan akan tugas dan tanggung jawab ketika dalam ladang misi. Sehingga misi bagi seluruh dunia dapat dijangkau dan membawa jiwa-jiwa datang kepada keselamtan yang kekal tersebut.

Sebagai utusan dan pengabdian kepada Tuhan maka pelayanan pemberitaan Injil, sebagai tindakan nyata yang tidak semata-mata menuntut balas dan upah, tetapi pelayanan yang secara sadar dilakukan dan digerakkan karena mengasihi Allah dan mengasihi sesamanya. ${ }^{60}$ Hal itu sebagai kontribusi dalam ketaatan dan ketundukannya terhadap mandat Amanat Agung Tuhan Yesus. yang dilakukan dengan penuh tanggung dan dedikasi kepada Yesus Kristus. ${ }^{61}$ Untuk itu orang Kristen hendaklah tetap bersemangat untuk memberitakan Injil guna memenangkan jiwa bagi Yesus Kristus yang dikerjakan oleh Roh Kudus menjadi kekuatan untuk terus antusias dalam aktivitas penginjilan. ${ }^{62}$ Untuk pergi kepada bangsa-bangsa dimana Allah menempatkan para pekerjanya sesuai market place dengan tujuan untuk memberitakan Injil Kristus. ${ }^{63}$ Sebab pemberitaan Injil bagi keselamatan manusia adalah anugrah dan keselamatan terbaik menjadi kawan sekerjanya Tuhan. ${ }^{64}$ seperti yang disampaikan oleh Oci bahwa esensi misi adalah tindakan pengabdian dan kerjasama antara manausia dan Allah. Atau dengan kata lain pemberitaan Injil merupakan pengkomunikasian orang percaya sebagai kawan sekerja Allah atau sebagai penyambung suara dari Allah untuk memberitakan kabar pengampunan Allah kepada

\footnotetext{
${ }^{60}$ Santosa, "Pelayanan Sosial Sebagai Konteks Refleksi Aktivitas Misiologi."

${ }^{61}$ Damarwanti, "Pandangan Rasul Paulus Tentang Jembatan Pengantar Injil. Kajian Misiologi Terhadap I Korintus 9:1-23.”

${ }^{62}$ Hannas Rinawaty, "Menerapkan Model Penginjilan Pada Masa Kini,” Kurios (Jurnal Teologi Dan Pendidikan Agama Kristen) 5, no. 2 (2019): 175-89, https://www.sttpb.ac.id/ejournal/index.php/kurios/article/download/118/75.

63 J.I Packer, Penginjilan Dan Kedaulatan Allah (Surabaya: Momentum, 2003), 4.

${ }^{64}$ Stefany John Risna Abrahamsz and Petronella Tuhumury, "Model Penginjilan Dalam Yohanes 4:4-42 Dan Implementasinya Pada Masa Kini,” Jurnal Jaffray 10, no. 2 (2012): 104-39, https://doi.org/10.25278/jj71.v10i2.55.
} 
manusia berdosa. ${ }^{65}$ Yang bertujuan menghasilkan terobosan bagi manusia yang belum percaya untuk dapat menerima keselamatan dari Yesus Kristus. ${ }^{66}$ Seorang pemberita Injil pasti mengkomunikasikan pesan penting dari Injil, atau sebagai seorang penginjil yang baik menyampaikan Injil keselamatan dalam Yesus supaya gampang dan efektif dapat diterima oleh pendengarnya hanya dengan mengandalkan pekerjaan Roh Kudus untuk berperan dalam penginjilannya. ${ }^{67}$ Penginjil juga harus dapat memberikan dirinya sebagai teladan bagi sesama sebab keteladanan merupakan perintis atau pembuka jalan untuk orang lain menjadi respon dengan pemberitaan Injil. Sebagaimana dalam Kisah Para Rasul 2:46-47 dituliskan sikap keteladanan umat Tuhan disukai oleh semua orang yang menyebabkan bertambahnya orang percaya. ${ }^{68}$ Namun yang perlu diperhatikan dalam mengaktualisasi misi, Yesus memerintahkan agar orang Kristen sebagai pengikut-Nya mewujudkan kasih yang tulus kepada sesama. Dengan kasih yang tulus dan hati yang memperhatikan dan menghargai kemanusiaan menjadi jalan masuk pada kesaksian yang membawa nama Tuhan. sebab kasih yang tulus akan menciptakan kerukunan dan keharmonisan dengan sesama tanpa memandang perbedaan yang ada di dalamnya. ${ }^{69}$

\section{KESIMPULAN}

Allah telah merencanakan penyelamatan umat manusia sejak kejatuhan manusia ditaman Eden tersebut kedalam pelanggaran dan dosa. Allahlah yang berperan aktif dan kreatif dalam

\footnotetext{
${ }^{65}$ Packer, Penginjilan Dan Kedaulatan Allah, 50.

${ }^{66}$ Markus Oci, "Implikasi Misiologi Dalam Pengembangan Kurikulum Agama Kristen Di Gereja Lokal," FIDEI: Jurnal Teologi Sistematika Dan Praktika 2, no. 1 (2019): 81-99, https://doi.org/10.34081/fidei.v2i1.29. ${ }^{67}$ Daniel Sutoyo, "Peran Roh Kudus Dalam Pemberitaan Injil," Journal of Chemical Information and Modeling, 2013, https://doi.org/10.1017/CBO9781107415324.004.

${ }^{68}$ Frans Wonatorei and Marciano Antaricksawan Waani, "Metode Penginjilan Yesus Kristus Menurut Injil Lukas," KHARISMATA: Jurnal Teologi Pantekosta 3, no. 2 (2021): 148-62, https://doi.org/10.47167/kharis.v3i2.54.

${ }^{69}$ Yonatan Alex Arifianto and Kalis Stevanus, "Membangun Kerukunan Antarumat Beragama Dan Implikasinya Bagi Misi Kristen,” HUPĒRETĒS: Jurnal Teologi Dan Pendidikan Kristen 2, no. 1 (2020): 39-51, https://doi.org/10.46817/huperetes.v2i1.44.
} 
keselamatan manusia tersebut. Inti dari keselamatan yang hakiki adalah keselamatan yang dinyatakan dalam Yesus. Ini yang harus diberitakan kepada manusia, namun paradigma dan hambatan internal maupun eksternal gereja mengubah hakikat dan Paradigma Penginjilan itu sendiri. Oleh karena itu Kajian Teologi Misi dalam Roma 10:13-15 terhadap Aktualisasi Misi Kristen yang dikaji melalui eksegesa dapat disimpulkan bahwa, Pertama Penginjilan harus terus dilakukan sebabgai bagian aktualisasi mandat Amanat Agung dengan memberi diri untuk memberitakan kabar bagi sesama sehingga orang yang belum mengenal Yesus dapat mendengar keslematan hanya didalam Yesus. Kedua, Tugas orang percaya dilanjutkan sebagai pribadi yang terus menerus melakukan pemberitaan dengan memperdengarkan dan memberitakan Injil keselamatan bagi manusia. Ketiga Gereja atau pemimpin wajib mengirimkan utusan Pemberita Injil demi jiwa-jiwa diselamatkan.

\section{REFERENSI}

Abrahamsz, Stefany John Risna, and Petronella Tuhumury. "Model Penginjilan Dalam Yohanes 4:4-42 Dan Implementasinya Pada Masa Kini.” Jurnal Jaffray 10, no. 2 (2012): 104-39. https://doi.org/10.25278/jj71.v10i2.55.

Ambarita, Darsono. Perspektif Misi Dalam Perjanjian Lama Dan Perjanjian Baru. Medan: Pelita Kebenaran Press, 2018.

Andriani, Sarah. "Refleksi Guru Pendidikan Agama Kristen Sebagai Misionaris Di Dalam Pendidikan.” Jurnal Antusias: Jurnal Teologi Dan Pelayanan 2, no. 4 (2013): 1-16.

Anggraini, Nidia, and Dicky Dominggus. "Mengajarkan Sikap Patriotisme Melalui Pemaknaan Roma 9:3.” LOGIA: Jurnal Teologi Pentakosta 1, no. 2 (2020): 23-40. https://doi.org/10.37731/log.v1i2.34. 
Arifianto, Yonatan Alex, Kristien Oktavia, and Matius I Totok Dwikoryanto. "Studi Teologis Prinsip Penginjilan Paulus Dalam 1 Korintus 9: 16.” LOGIA: Jurnal Teologi Pentakosta 2, no. 1 (2020): 22-41. https://doi.org/10.37731/log.v2i1.42.

Arifianto, Yonatan Alex, and Kalis Stevanus. "Membangun Kerukunan Antarumat Beragama Dan Implikasinya Bagi Misi Kristen.” HUPËRETẼS: Jurnal Teologi Dan Pendidikan Kristen 2, no. 1 (2020): 39-51. https://doi.org/10.46817/huperetes.v2i1.44.

Baito, Linus. "Faktor Meme Dalam Penginjilan: Sebuah Pendekatan Interatif Dalam Memahami Roma 10:14-15 Berdasarkan Perspektif Meme Machine.” SOLA GRATIA: Jurnal Teologi Biblika Dan Praktika 6, no. 2 (2020). https://doi.org/10.47596/solagratia.v6i2.79.

Bibleworks, BibleWorks ceased operation as a provider of. "BibleWorks," 2018.

Bosch, David J. Tranformasi Misi Kristen, Sejarah Teologi Misi Yang Mengubah Dan Berubah. Jakarta: BPK Gunung Mulia, 2018.

—. Transformasi Misi Kristen Sejarah Teologi Misi Yang Mengubah Dan Berubah. Jakarta: BPK Gunung Mulia, 2000.

Camerling, Yosua Feliciano, and Hengki Wijaya. "Misi Dan Kebangkitan Rohani: Implikasi Misi Allah Bagi Gereja.” Jurnal Ilmiah Religiosity Entity Humanity (JIREH) 1, no. 1 (2019): 57-71.

Damarwanti, Seri. "Pandangan Rasul Paulus Tentang Jembatan Pengantar Injil. Kajian Misiologi Terhadap I Korintus 9:1-23.” Sanctum Domine: Jurnal Teologi 8, no. 2 (2020): 95-132. https://doi.org/10.46495/sdjt.v8i2.53. 
Eckhard J. Schnabel. Paul The Missionary. Downers Grove: InterVarsity, 2008.

Ellis, David W. Metode Penginjilan: Istimewa Tepat Guna Bagi Penginjil Awam Praktis Dan Taktis. Yayasan Komunikasi Bina KASIH/OMF, 2005.

Harming, Harming. "Metode Penginjilan Yesus Dalam Injil Yohanes 4:1-42." Evangelikal: Jurnal Teologi Injili Dan Pembinaan Warga Jemaat 1, no. 2 (2017): 162. https://doi.org/10.46445/ejti.v1i2.73.

Henry's Matthew. "Matthew Henry Commentary On Whole Bible," 2002. https://www.biblestudytools.com/commentaries/matthew-henry-complete/Kisah Para Rasul/2.html.

Henry Matthew Commentary, Tafsiran Online. "Henry Matthew Commentary, Tafsiran Online.," n.d.

Hutahaean, Tumpal H. “Signifikansi Apologetika Dalam Penginjilan.” Stulos 17, no. 1 (2019): 54-74. http://www.sttb.ac.id/jurnal-teologi-stulos-vol-17-no-1.

Kristian, Alvin. "Pemberitaan Injil Di Tengah Masyarakat Pluralis." Excelsis Deo: Jurnal Teologi, Misiologi, Dan Pendidikan 3, no. 1 (2019): 123-32. https://doi.org/10.51730/ed.v3i1.5.

Laia, Kejar Hidup. "Pertumbuhan Gereja Dan Penginjilan Di Kepulauan Nias.” FIDEI: Jurnal Teologi Sistematika Dan Praktika 2, no. 2 (2019): 286-302. https://doi.org/10.34081/fidei.v2i2.46.

Manurung, Kosma. "Efektivitas Misi Penginjilan Dalam Meningkatkan Pertumbuhan Gereja.” 
DUNAMIS: Jurnal Teologi Dan Pendidikan Kristiani 4, no. 2 (2020): 225-33. https://doi.org/10.30648/dun.v4i2.242.

Mendrofa, Adinia. “Analisis Tentang Keselamatan Menurut Roma 10: 4-15 Dan Aplikasinya Bagi Orang Percaya." HAGGADAH: Jurnal Teologi Dan Pendidikan Kristen 1, no. 2 (2020): 87-93.

Oci, Markus. "Implikasi Misiologi Dalam Pengembangan Kurikulum Agama Kristen Di Gereja Lokal." FIDEI: Jurnal Teologi Sistematika Dan Praktika 2, no. 1 (2019): 81-99. https://doi.org/10.34081/fidei.v2i1.29.

Packer, J.I. Penginjilan Dan Kedaulatan Allah. Surabaya: Momentum, 2003.

Pandie, Mira Marleni. "Misteri Allah Dalam Pandangan Paulus Dan Implikasinya Bagi Pemberitaan Masa Kini.” Jurnal Jaffray, 2012. https://doi.org/10.25278/jj.v10i2.059.166179.

Peters, George W. Teologi Alkitab Tentang Pekabaran Injil. Malang: Gandum Mas, 2006.

Purwoto, Paulus, and Asih Rachmani Endang Sumiwi. "Pola Manajemen Penginjilan Paulus Menurut Kitab Kisah Para Rasul 9-28." Angelion: Jurnal Teologi Dan Pendidikan Kristen 1, no. 2 (2020): 113-31. https://doi.org/10.38189/jan.v1i2.71.

Putra, Gratia Yada, Priskila Issak Benyamin, Yuel Sumarno, and Valentino Wariki. “Pengembangan Model Pendidikan Agama Kristen Bagi Anak Korban Kemiskinan.” Jurnal Ecodunamika 3, no. 1 (2020).

Rick Meyers. "E-Sword®.” Franklin, TN 37065 United States of America: Rick Meyers All 
Rights Reserved Worldwide, 2020.

Rinawaty, and Hannas. "Menerapkan Model Penginjilan Pada Masa Kini." Kurios (Jurnal Teologi Dan Pendidikan Agama Kristen) 5, no. 2 (2019): 175-89. https://www.sttpb.ac.id/ejournal/index.php/kurios/article/download/118/75.

Rinawaty, Hannas. "Menerapkan Model Penginjilan Pada Masa Kini.” Kurios (Jurnal Teologi Dan Pendidikan Agama Kristen) 5, no. 2 (2019): 175-89. https://www.sttpb.ac.id/ejournal/index.php/kurios/article/download/118/75.

Rusli, Gideon, and Yonatan Alex Arifianto. "Tinjauan Teologis Peran Gembala Dalam Aktualisasi Misi Berdasarkan 2 Timotius 4: 1-2.” Sabda: Jurnal Teologi Kristen 2, no. 1 (2021): 299-316.

Santosa, Nur Budi. "Pelayanan Sosial Sebagai Konteks Refleksi Aktivitas Misiologi.” Jurnal Antusias 2, no. $4 \quad$ (2013): 126-37. $\quad$ http://sttintheos.ac.id/ejournal/index.php/antusias/article/view/28/27.

Setiawan, David Eko. "Dampak Injil Bagi Transformasi Spiritual Dan Sosial.” BIA': Jurnal Teologi Dan Pendidikan Kristen Kontekstual 2, no. 1 (2019): 83-93.

Sills, M. David. Panggilan Misi. Surabaya: Momentum, 2011.

Stephanus, Djuwansah Suhendro P. "Mengajarkan Penginjilan Sebagai Gaya Hidup Orang Percaya." Redominate 1, no. 1 (2019): 12-22.

Stevanus, Kalis. "Bukti Keilahian Yesus Menurut Injil.” Jurnal Teruna Bhakti 2, no. 2 (2020): 82. https://doi.org/10.47131/jtb.v2i2.49. 
—. "Relevansi Supremasi Kristus Bagi Pemberitaan Injil Di Indonesia: Eksegesis Injil Yohanes 14: 6." KAMASEAN: Jurnal Teologi Kristen 2, no. 1 (2021): 32-46.

Sutoyo, Daniel. "Peran Roh Kudus Dalam Pemberitaan Injil." Journal of Chemical Information and Modeling, 2013. https://doi.org/10.1017/CBO9781107415324.004.

Talan, Yesri. "Mengkaji Hakekat Misi Inklusif Yesus Berdasarkan Injil Lukas Dan Aplikasinya Bagi Misi Masa Kini.” Manna Rafflesia 6, no. 2 (2020): 200-219.

Tambunan, Fernando. "Tantangan Misi Dalam Prespektif Pemikiran Era Postmodern." In Seminar Mission Today, 2017. https://doi.org/10.1017/CBO9781107415324.004.

Tomatala, Yakob. Penginjilan Masa Kini 1. Malang: Gandum Mas, 2018.

Tridarmanto, Yusak. "Spiritualitas Rasul Paulus." Gema Teologi: Jurnal Teologi Kontekstual Dan Filsafat Keilahian 39, no. 1 (2015): 15-32. https://journaltheo.ukdw.ac.id/index.php/gema/article/view/191.

Umrati, and Hengki Wijaya. Analisis Data Kualitatif Teori Konsep Dalam Penelitian Pendidikan. Sulawesi Selatan: Sekolah Tinggi Theologia Jaffray, 2020.

Widjaja, Fransiskus Irwan, Daniel Ginting, and Sabar Manahan Hutagalung. "Teologi Misi Sebagai Teologi Amanat Agung." Thronos 1, no. 1 (2019): 17-24.

Wonatorei, Frans, and Marciano Antaricksawan Waani. "Metode Penginjilan Yesus Kristus Menurut Injil Lukas.” KHARISMATA: Jurnal Teologi Pantekosta 3, no. 2 (2021): 148-62. https://doi.org/10.47167/kharis.v3i2.54.

Zakaria, M R B. “Metode Penginjilan Dalam Agama Kristen Katolik.” Universitas Islam Negeri 
Sultan Syarif Kasim Riau, 2011. http://repository.uin-suska.ac.id/206/. 